\title{
$\operatorname{or}_{3 u J b}^{c}$ \\ n.s. v. $3^{3}$
}

\section{UNIVERSITY OF OREGON BULLETIN}

New Series.

\%, Vol. III, No. 3.

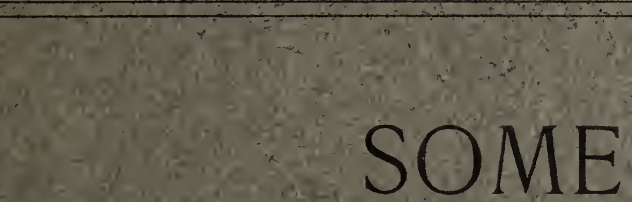

\section{BOTANICAL NOTES}

FROM THE

\section{BIOLOGICAL LABORATORY}

ALBERT R. SWEETSER, PROFESSOR OF BIOLOIGY University of Oregon. State Biologist

Issued Bi-Monthly. Published by the University, Eugene, March 1906 Entered January 9, 1904, at Eugene, Cregon, as Second Class Matter, under Act of Congress of July 16,1894 .: 



\section{SOME}

\section{BOTANICAL NOTES}

FROM THE

BIOLOGICAL LABORATORY

ALBERT R. SWEETSER, PROFESSOR OF BIOLOGY University of Oregon. State Biologist 


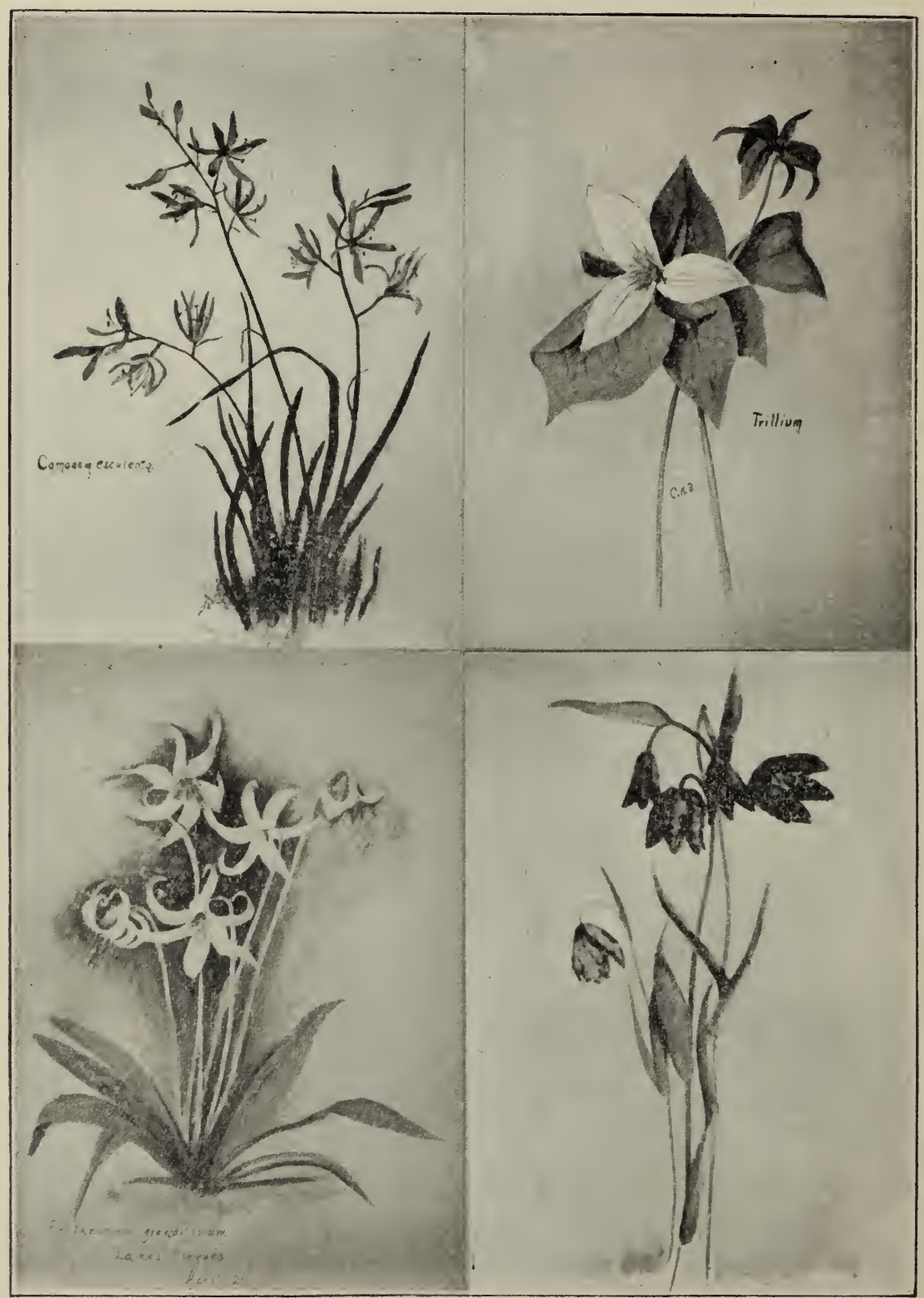

Plate A. 
Taxonomy or the study of the names of plants onceconstituted the major part of botany. The most of the time was given to the collection of flowers and the preparation of herbaria, and only such attention was given to structure as would be necessary for classification. This meant much field work and brought the student close to nature and in many ways was admirable. But the new botany tends more to the study of the plant as a living thing, its anatomy, physiology, distribution, its environment, and the mutual relation of plants and animals in all their parts. The ability to recognize the flowers we find, is however, an important part of botany and requires some knowledge of structure. The following notes suggest material easily obtainable which can be used to develope the essential knowledge of structure.

Nothing of novelty is claimed for the following outlines, but ratler a suggestion as to the handling of easily obtainable material. They may be used by the instructor in an elementarv course in botany or by the teacher in the grades for a course in nature study.

The teacher with a little forethought may collect much of this material during the summer vacation and press for future use.

A simple magnifying glass costing a dollar will be a very effective help in plant study.

\section{BEAN}

Seed. This should be soaked for a short time until the coat can be removed easily. Within will be found the little stem (caulicle) - two fleshy leaves (cotyledons) and two true leaves (plumule). Make drawings before the removal of the coat, and of the parts within, carefully labelling.

Plantlet. Study the young plant. Note the straight root (simple primary); the withering of the cotyledons due to the removal of the nourishment which they contain, by the growing plant;

the point at which the leaves are borne (nodes);

the veining of the first leaf (net veined);

the flat paat of the leaf (blade); and the leaf stem (petiole).

Compare the subsequent leaves with the first. These are compound leaves made up of three leaflets. IVhere the leaf is joined to the stem is a pair of growths (stipules); while smaller ones are found where the leaflets join the leaf-stem (stiples).

Note also the arrangement of the leaves on the stem (opposite). Cut across the stem with a sharp knife or razor and examine with a good magnifying glass. A ring of fibers can be seen toward the outer edge. This is a so-called outside-grower (exogen).

Make carefully labelled drawings to show these points.

CORN

Seed. This also should be soaked until the coat can be removed. On one side can be seen the single cotyledon occupying only a portion of the seed and surrounded by starch, which in the bean is inside 

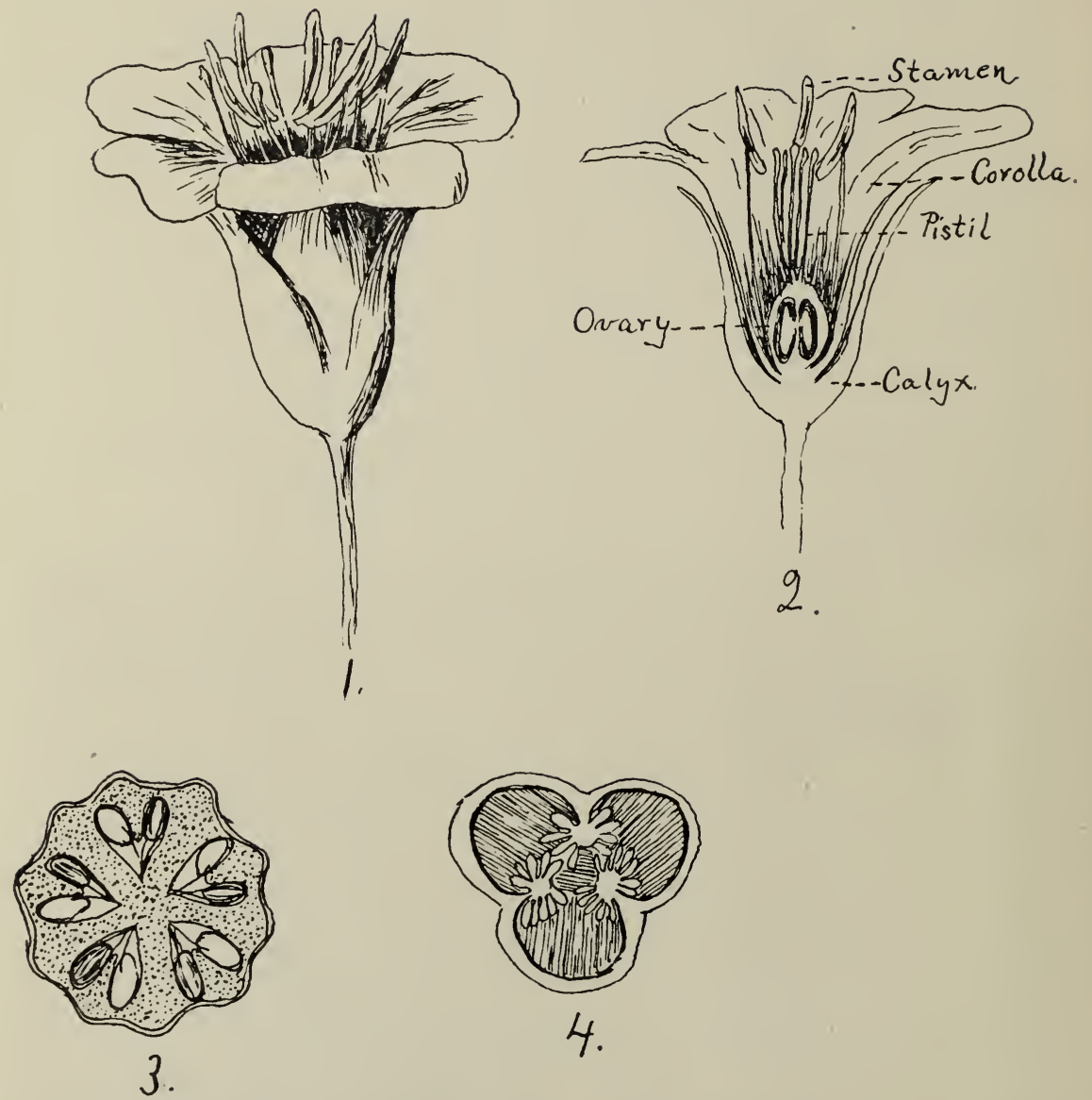

Plate B-1, Flax flower. 2, Longitudinal section. 3, Cross section of ovary. 4, Cross section of a compound ovary with three attachments. 
the cotyledon and forms the principal part of the same. By removing the coat it is possible to show that the cotyledon is single. Cut the seed lengthwise in a plane parallel to the edge when the relation of the parts can be clearly made out. Make drawings to show these points.

Plantlet. Study the leaf noting its veining (parallel veined) comparing it with the bean.

Cut across the stem, preferably a well developed stalk, and with a magnifying glass observe the fibers scattered all through the structure. This is a so-called inside grower (endogen). Compare with the bean. Roots are of ten to be found springing out from the stem above the first roots (secondary roots).

These are types of the two great divisions of the flowering plants and from them the following summary may be made which is applicable to most of the members of these divisions.

Dicotyledons (bean the type) Two cotyledons; leaves net reined; fibers, which at length become rings of growth, on the outside.

Monocotyledons (corn the type) One cotyledon; leaves parallel veined; fibers, not becoming definite rings, scattered all through the stem.

\section{LEAF}

Mode of veining (venation) Use the leaf of the common household geranium. This has blade, petiole and stipules. On lolding to the light it is seen to be net veined, but on comparing it with one of the leaflets of the bean the plan of venation is seen to differ. The bean has a single mid-vein with secondary veins springing from it, (feather or pinnately veined). The geranium lias several primary veins springing from the same point, something like the fingers of the hand (palmately veined).

Summary of Venation.

Parallel Veined.

Net Veined.

Pinnately Net.

Palmately Net.

Arrangement.

Opposite, as in bean.

Alternate, the usual method in geranium.

Whorled, several leaves springing from the same point as in some lilies.

Shapes.

Linear, grasses and firs.

Oblong, box, rhododendron.

Elliptic, tapering to both ends from middle, alder.

Lancealate, widest below the middle, some willows.

Spatula, below, like a spatula, rounded above, long and narrow. 


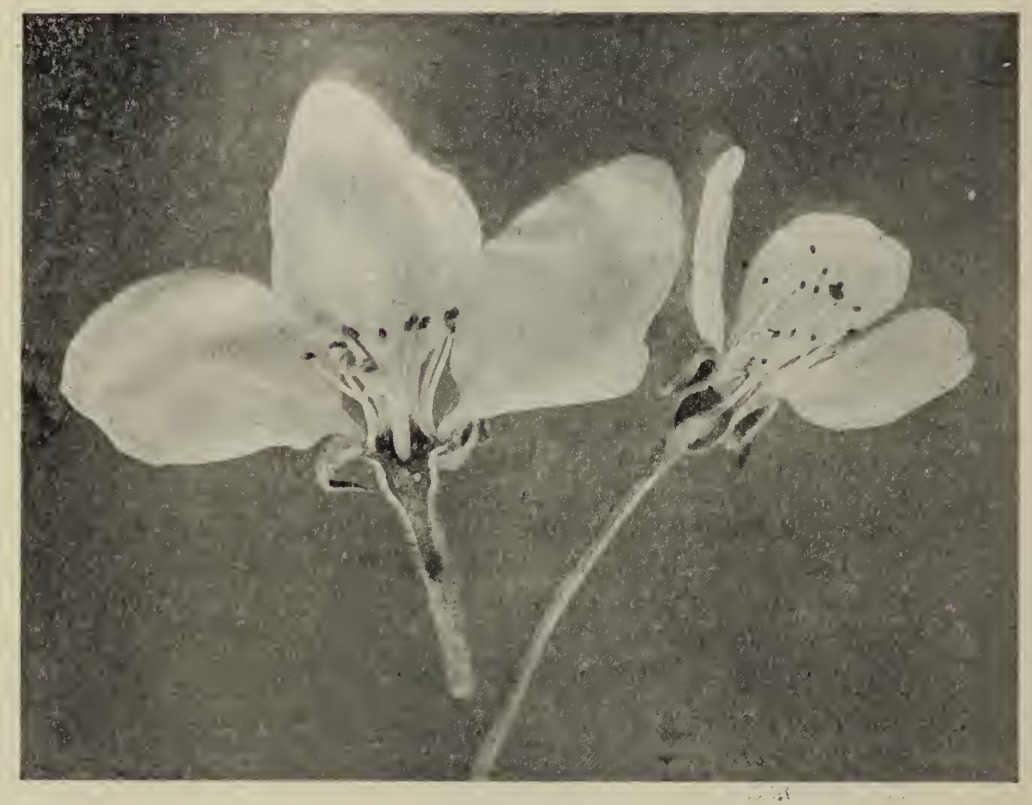

PLatf C.-Cherry and apple blossom.

$$
\text { / }
$$


Ovate, like a lengthwise section of a hen's egg, the broader end downward, popular.

There are numerous other shapes and many are combinations of two.

\section{Margins.}

Entire, when edge is even line.

Dentate, toothed, Oregon Grape.

Serrate, saw-toothed, with teeth pointing forward; leaflets of rose. Crenate, scalloped.

Lobed, soniewhat deeply cut but not farther than half way to the center and the divisions more or less rounded, Oak.

Cleft, when extended half way to the center or more and sharp.

Parted, divisions deeper but not quite reaching the center.

\section{Compound Leaves.}

When the divisions extend to the middle they produce leaflets and the leaf is compound.

Study a Rose Leaf. Stipules are present at the base and the petiole is continued as a main rib with the leaflets disposed on each side. This is called Pinnately Compound.

Stuly a Clover Leaf (be sure and get all of it). Stipules are present and a petiole which at its sumunit divides into three parts and then become the ribs of the three leaflets. Such an arrangement with leaflets radiating from a common point is called Palmately Compound.

\section{FLOWER}

Study the Flax flower (Plate B). All the parts of the flower are modified leaves. Beginning from the outside the first floral envelope $($ caly $x)$ is composed of green parts (sepals) which are distinct from each other (polysepalous) and are borne on the top of the flower-stem (receptacle).

The next envelope (carolla), consists of parts (petals) which are distinct (polypetalous) and borne on the receptacle.

Next in order are (stamens) consisting of supporting portion (filament) with the pollen-bearing part (anther), the top. At the center in the pistil having the supporting portions (styles), at the top of the style the polen-receptive portion (stigma); and the lower portion (ovary) containing the little eggs (ovules) which are to develop into seeds. All these parts are seen to allvantage in (Plate B, Fig 2.) A cross-section of the ovary (Plate B, Fig 3) shows it to be made up of five cells or fruiting leaves (carpels), with the ovules attachments (placenta) at the center. Such an ovary and any made up of more than one carpel is called compound.

The parts which are attached distinctly under the ovary, as are all in the flax, are called (hypogynous). In this example also the calyx being 


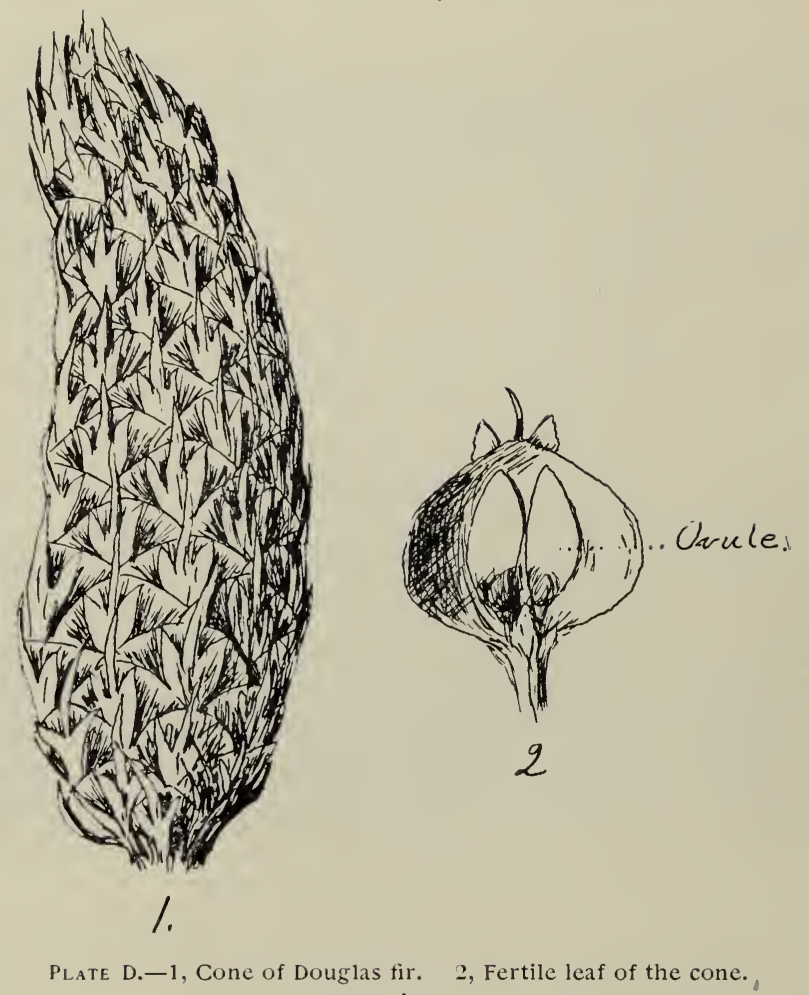


wholly beneath and free from the ovary it is spoken of as (inferior) while the ovary would be superior.

Draw and carefully label all these parts.

CHERRY BLOSSOM (Plate C)

Compare with flax, and make out all the parts. The calyx is on the receptacle beneatl the ovary (inferior) but the sepals are united (gamosepalous) into a cup which carries the petals and stamens on the rim (perigynous).

The pistil has but one style with its stigma, and a section of the ovary shows but one cell, with one or two hanging ovules. The ovary would be ( simple).

APPLE BLOSSOM (Plate C.)

Compare with flax and clierry and make out the parts. The calyx in its lower portion is united to the ovary (calyx superior, ovary inferior). The stamens and petals seem to rise from the top of the ovary. Section of the ovary shows it to be made up of several carpels with ovules at the center (ovary compound.)

BUTTERCUP.

Compare with other flowers. The point to be brought out is presence of many distinct pistils each with a single ovule (Plate I, Fig 3).

Make drawings to fix all the foregoing points.

Summary.

Calyx. Sepals may be distinct (polysepalous).

Sepals may be united to each other (gamosepalous).

May be borne under the ovary and free from it (inferior).

May be more or less attached to ovary (superior).

Corolla. Petals may be distinct (polypetalous).

Petals may be united with each other (gamopetalous) Exs. Primrose, Morning Glory, Madrone.

Petals may be borne, beneath the ovary (hypogynous)

on caly $x$ around the ovary (perigynous) on top of ovary (epigynous).

Pristle. Maybe composed of one carpel or several distinct carpels, (simple) Ex. Buttercup.

May be composed of several carpels grown together (compound) shown by the number of styles or by the section of the ovary. Ex. Flax, Apple.

Floral Arrangement.

Solitary. Either at the end of a flower-stem, or in the angle between a leaf and the stem (axil).

Raceme. Flowers on the sides of a flowering-stem with small leaves (bracts) where they spring from the stem. Exs. Oregon Grape, Currant. 


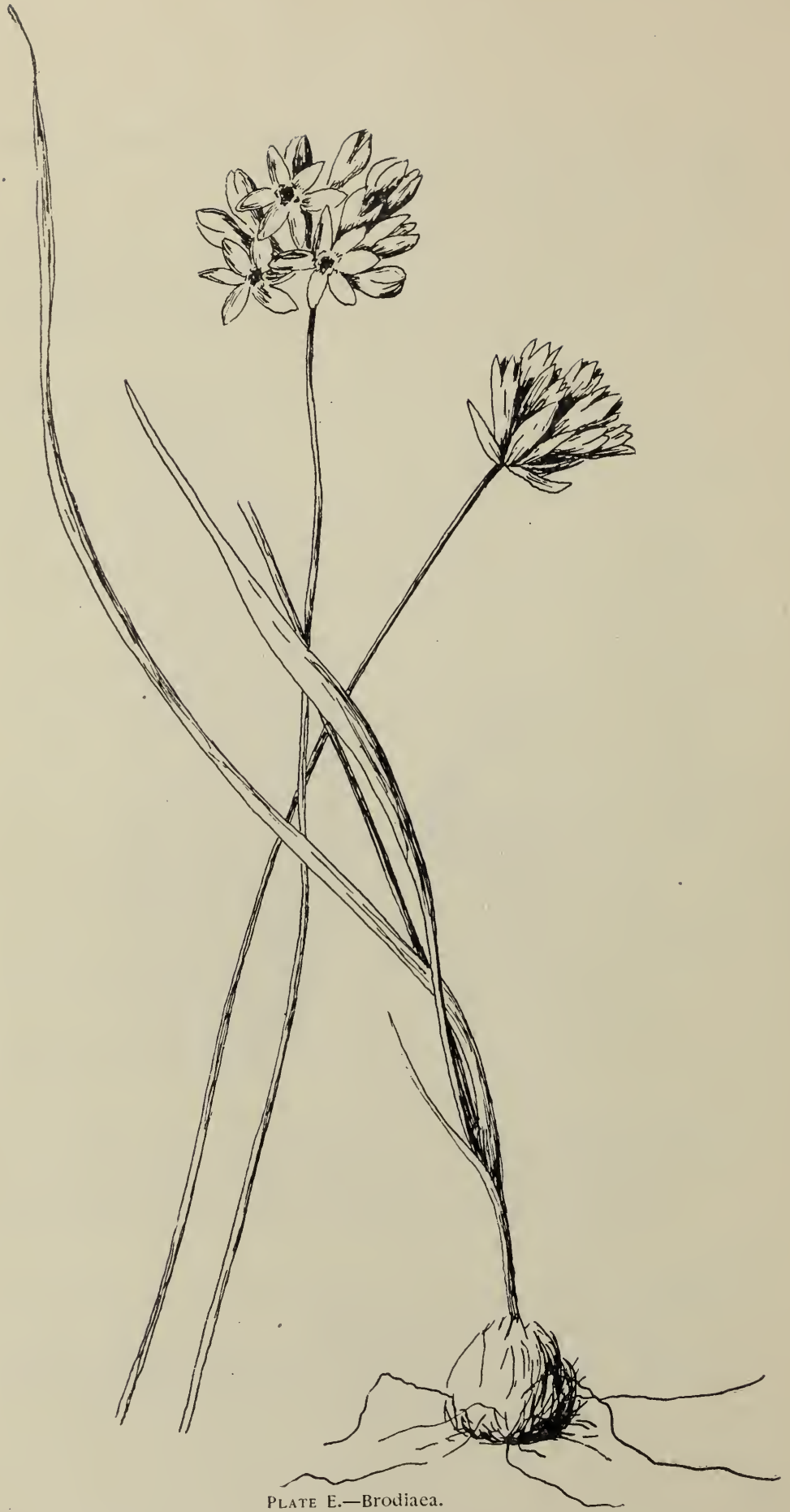


Catkin and Spike. Raceme with crowded and stemless flowers. Exs. Willow, Alder, Plantain.

Corymb. A cluster with flowers coming from different levels but even on top. Ex. Pear.

Umbel. A cluster composed of numerous flowers all springing from the same point. Ex. Cherry. (Plate C.)

Head. Crowded cluster, earliest flowers at outside. Exs.

Dogwood, Dandelion.

Cyme. Earliest flower at end of stem, subsequent ones below. Ex. Buttercup. (Plate H.)

\section{The Collecting and Preserving of Plants. The Making of an Herbarium}

From examination of numerous herbaria sent to the Exposition it was evident that some had missed the purpose of the mounted flower. In many cases the mounting sheets were too small so that only a portion of the plant was shown. The dried specimen should show as much of the history of the plant as possible.

- All of the plant, including the roots, should be gathered if possible. A covered basket or other arrangement to prevent excessive wilting should be used. Many botanists use a long tin box called a vasculm. Some prefer to carry driers into the field and put the flowers into press at once. A portable press can be made of two thin cedar boards with stout leather straps. In this way sufficient pressure can be obtained to keep the plants in good shape until they are placed in permanent press.

The pressure does not need to be excessive, two boards and a large stone answer very well for a press. A newspaper page, folded across, serves for the flower sheet, a whole paper folded in the same way may serve for a drier. Better driers can be made from heavy felt carpet lining cut to the proper size. The plant is to be placed between the folds of the flower sheet with a label showing name of flower, locality, kind of soil and date. One is repaid for the time spent in carefully arranging the leaves and parts of the flower by the increased value and beauty of the pressed specimen. In filling the press first one or more driers are placed at the bottom, then a flower sheet, then another drier and so on until all the specimens are taken care of. On top place another board and a stone or other body of considerable weight. For the first few days the driers should be changed at least once a day. In changing driers start a new pile with a fresh drier then one of the flower sheets and so on. Do not remove the flower from the flower sheet until thoroughly dry. The first driers may be 


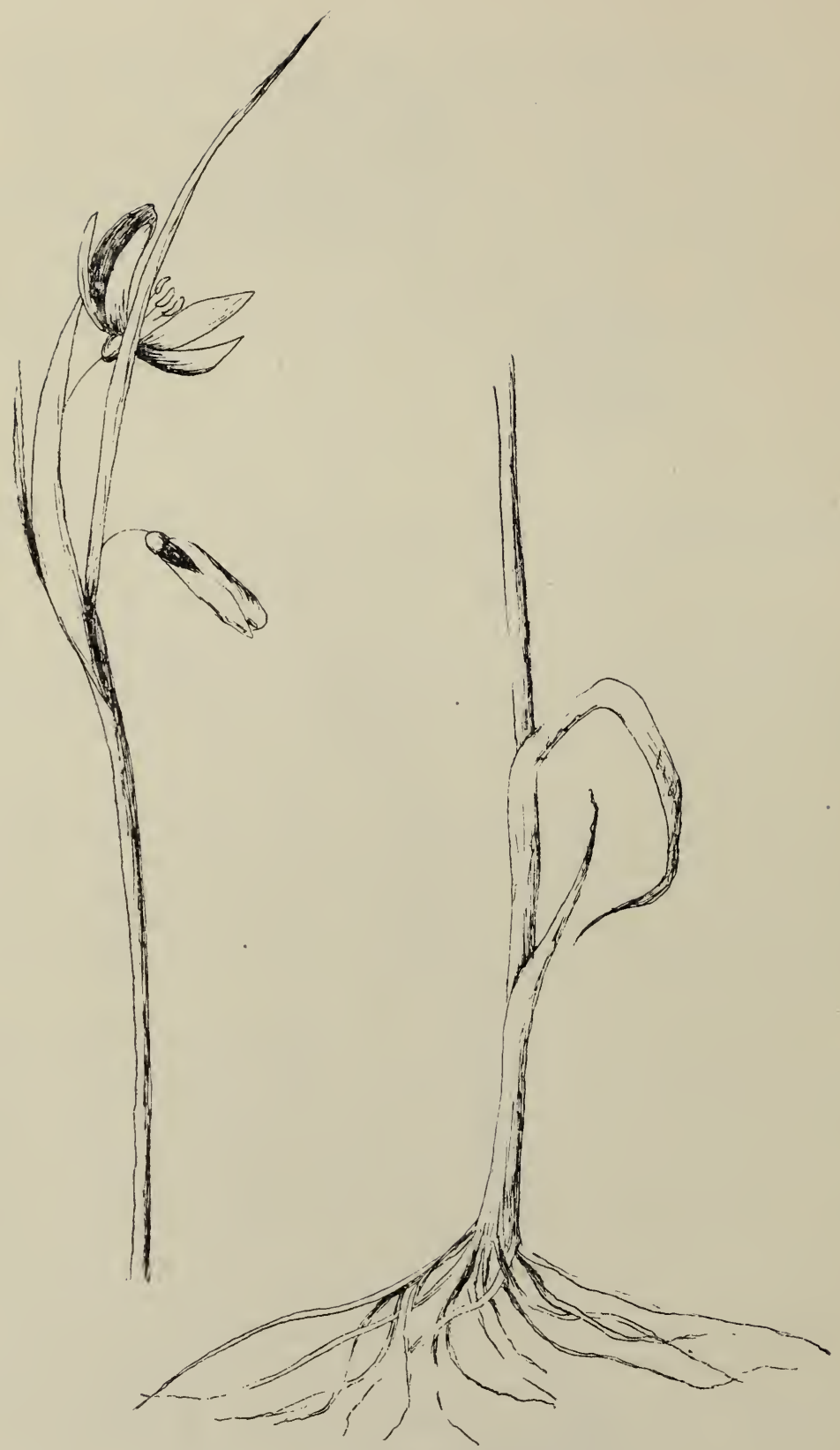

Plate F.-Sisyrinchium grandiflorum. [Dong. 
placed in the sun or near artificial heat and be ready for use at the next change.

The standard size of mounting sheet is $161 / 2 \times 11 / 2$. It may be of heavy paper or of cardboard. The stiffer the mount the less likelihood of breaking the specimen in handling. In the University Herbarium we use a cheap white cardboard obtained from the stock houses in Portland. We sacrifice without detriment a quarter of an inch on the width to make an economical cutting from the whole sheet.

The specimen may be affixed to the sheet by gluing, but this is bad as the glue sooner or later is apt to discolor the plant. The better plan is to bind the specimen to the sheet with slender bands of court plaster.

The label should show: I. the scientific name of the plant i. e. the genus and species; 2 . the common nanies; 3. the locality and nature of soil and environment; 4. Date; 5. Collector's name.

Some prefer not to mount the specimens on a sheet but fold brown paper the size of a mounting sheet and place the dried plant with its label therein. This has the advantage of allowing the specinen to be examined on both sides; the disadvantage that flowers are easily misplaced or broken in handling.

A few plants carefully studied out and presserl and mounted are often as valuable as great numbers hastily collected and poorly mounted.

For the written description of a plant, blanks are used and are an aid especially to teachers with large classes. But there is a danger that the pupil may fill out a large number of these in an automatic way not really understanding what he is about and if given a flower witlout his blank may be unable to give a serviceable description. It seems better that he should work without the blank, or if used it should be discarded after a while. It is true that spectacular work as to the number of flowers analyzed may be wanting, but the powers of observation and the use of concise English in an accurate description will be developed by this training, and that in our opinion is one of the most important objects of the study of botany and all nature.

\section{Tabular Index to a Few of the Early Oregon} Flowers

Cryptogams (flowerless) Includes alage, fungi, mosses, fern, etc.

Phenogams (flowering).

I. Gymnospermas (naked seeds). Includes pines, firs, cedars, etc., and all plants having the seeds lying exposed on the upper side of a scale, which scales form a cone. (Plate D.) 


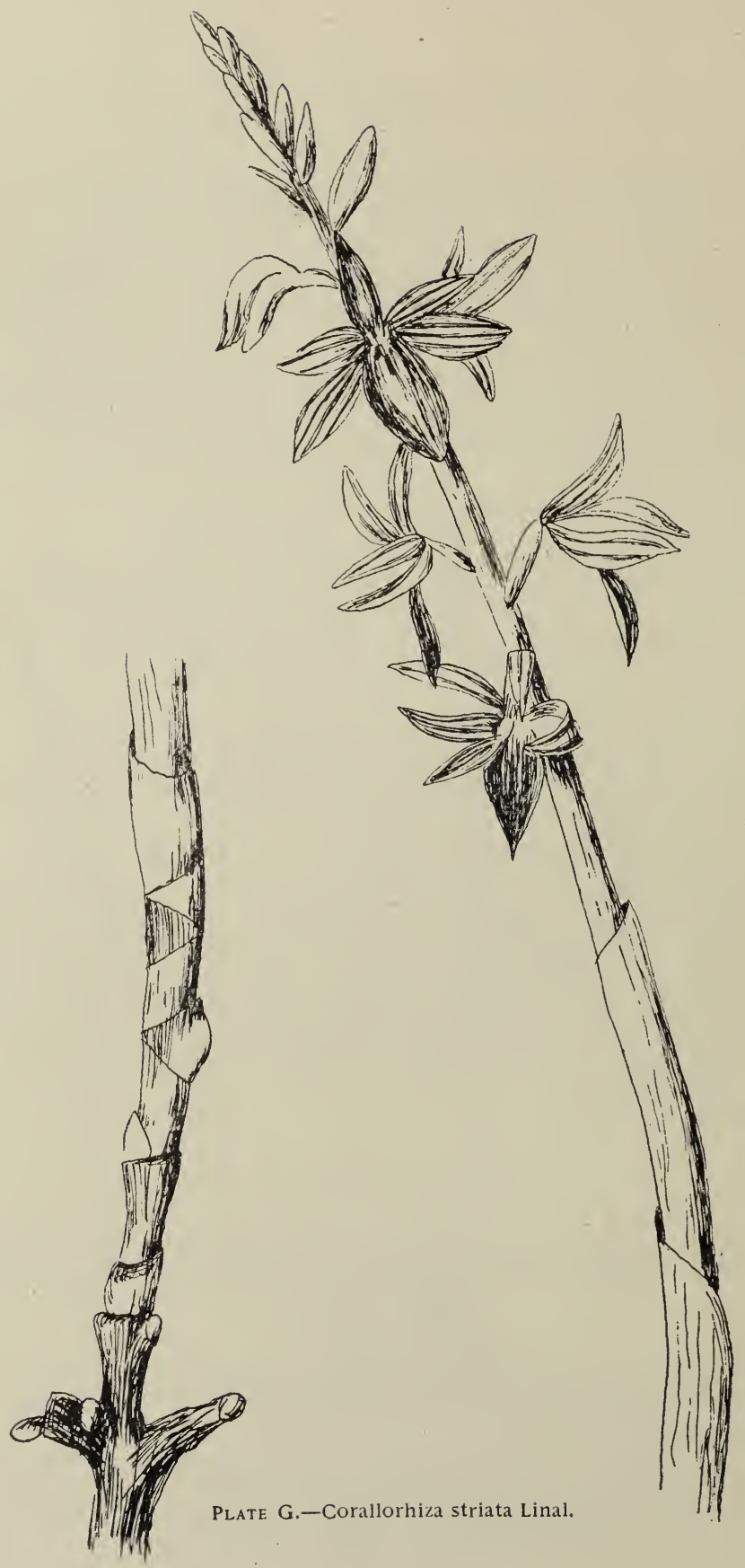


II. Angiospermas (covered seeds). All the plants having what are commonly called flowers, the seeds being in closed ovaries.

I. Monocotritedons (one cotyledon). Endogens, having no definite rings of growth, but bundles scattered through the stem. Leaves usually parallel veined. Flower on plan of three.

A. Grasses. No definite calyx or corolla. Leaves linear.

B. Definite Floral Envelope.

I) Floral envelope free from ovary, six stamens, Lily Family (Liliaceae).

2) Floral envelope united to ovary.

Three Stamens Iris Family (Iridaceae).

One fertile Stamen, flower irregular, Orchid Family (Orchidaceae).

2. Dicotyltidons (two cotyledons). Exogens, having definite rings of yearly growth. Leaves net veined, flower usually on the plan of four or five.

A. Apetalous. With one set of floral leaves, petals wanting. Here belong willow, alder, oak, etc.

B. Polypetalous. Petals entirely free from each other.

I. Stamens hypogynous (beneath the ovary). On the receptacle.

a. Ovary simple.

I) Pistils numerous and distinct. Buttercup Family (Ranunculaceae).

2) Pistil Single. Barberry Family (Berberidaceae).

b. Ovary compound.

I) Ovary one celled ovules attached on wall at two or more places (lateral placentaeae).

(a) Sepals two or three.

(I) Flowers regular Poppy Family (Papaveraceae).

(2) Flowers irregular Bleeding Heart Family (Fumariaceae).

(b) Sepals five, ovules attached at three points on wall. Violet Family (Violaceee).

2) Ovary one celled, ovules attached to axis, in center.

(a) Sepals two, Fleshy plants. Portulaca Family (Portulacaceae).

(b) Sepals as many as petals, not fleshy. Pink Family (Caryophyllaceae).

3) Ovary two celled, ovules on wall. Mustard Family (Cruciferae). 


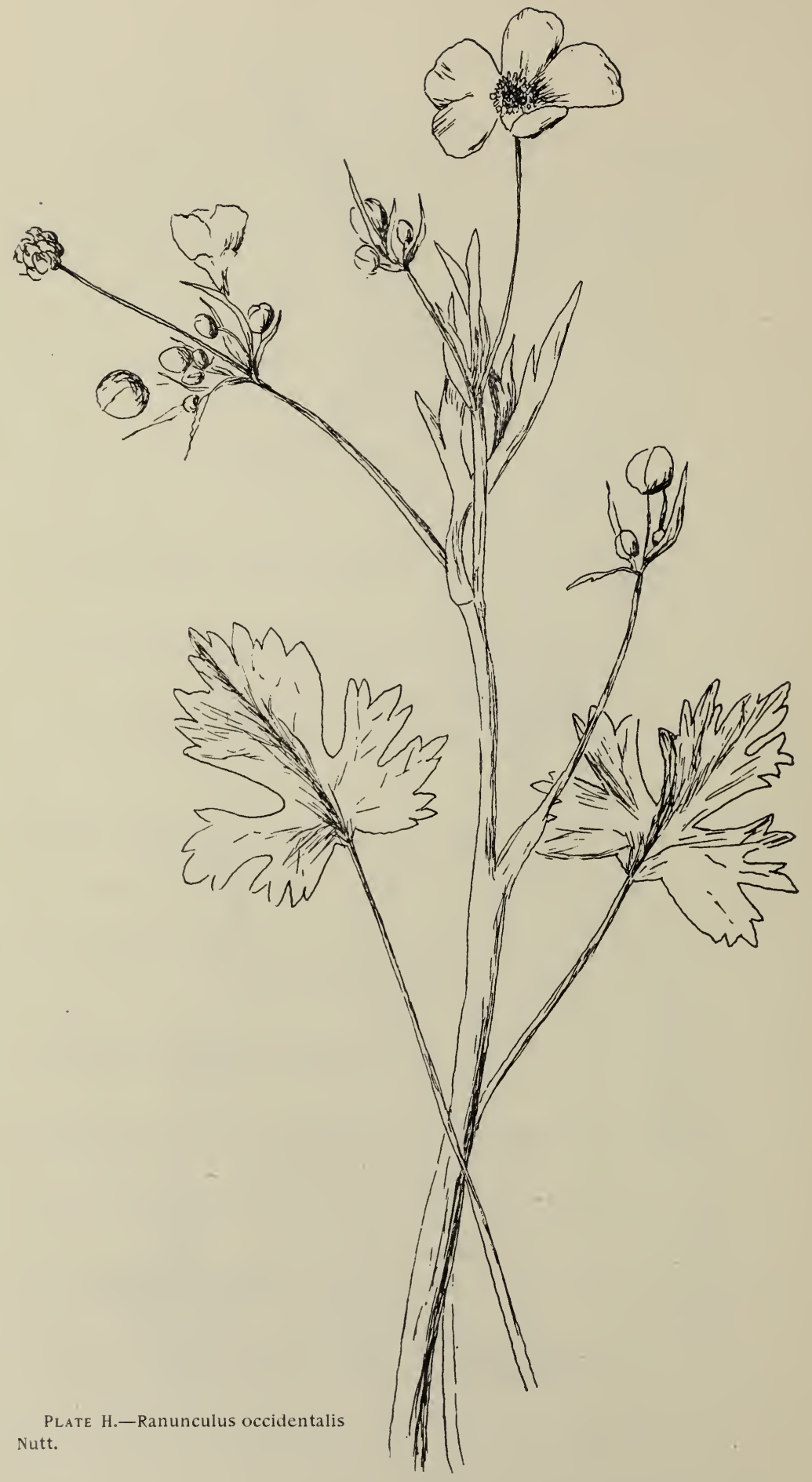


2. Stamens on calyx (perigynous) or on the ovary (epigynous)

a. Ovary simple and free from calyx (ovary superior).

I) Flower irregular, fruit a one celled pod. Pea Family (Leguminosae).

2) Flower regular. Rose Family. (Rosaceae).

b. Ovary Compound.

I) Flowers in umbels, a single ovule in each cell. Parsley Family (Umbelliferae).

2) Flowers not in umbels.

(a) Seeds two in each cell, fruit a fleshy pome. Apple Family (Pomaceae).

(b) Seeds usually numerous, fruit not fleshy. Saxifrage Family (Saxifragaceae)

C. Gamopetalous, petals more or less united to each other.

I. Calyx and ovary more or less united (ovary inferior).

a. Ovary one celled, numerous flowers forming a head.

Sunflower Family (Compositae).

b. Ovary more than one celled.

I. Ovary with numerous ovules. Harebell Family (Campanulaceae).

2. Ovary with few ovules. Honeysuckle Family (Caprifoliaceae).

2. Calyx and ovary distinct (ovary superior).

a. Corolla irregular.

I. Ovary four lobed, stem four angled. Mint Family (Labiatae).

2) Ovary two celled, numerous ovules in each cell. Figwort Family (Scrophulariaceae).

b. Corolla regular.

I) Ovary one celled.

(a) Ovules on wall of ovary (parietal placenta).

Leaves opposite. Gentian Family (Gentianaceae).

Leaves alternate, ovary sometimes two celled. Baby-eyes Family (Hydrophyllaceae).

(b) Ovules on a central axis (free-central placenta) Primrose Family (Primulaceae).

2) Ovary two celled.

Ovules numerous. Nightshade Family (Solonaceae).

Ovules usually four. Morning Glory Family (Convolvulaceae).

3) Ovary three celled, ovules attached at center. Phlox Family (Polemoniaceae). 

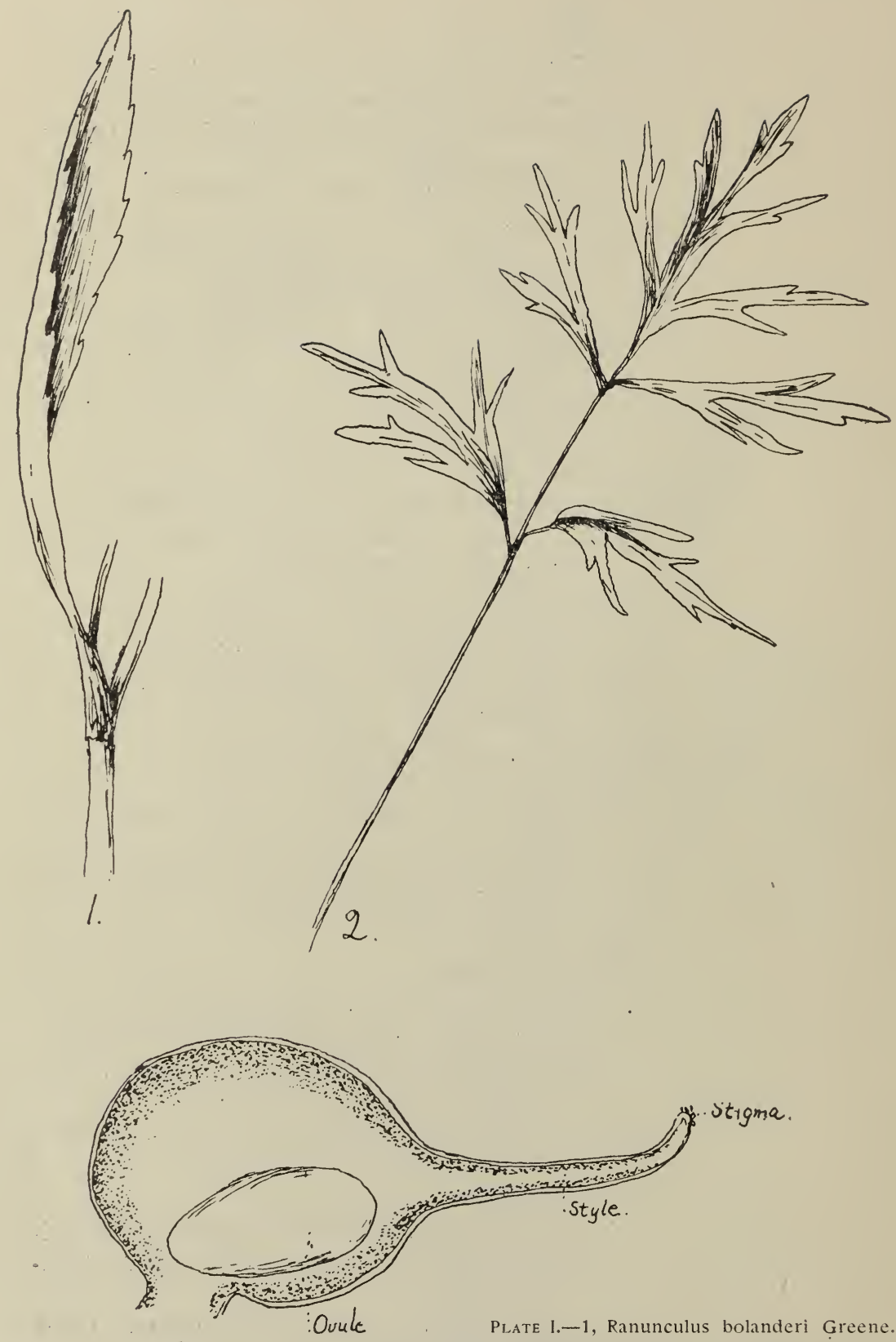

3. Ovary.

2, R. orthorhynchus Hook. 3, Section of ovary of ranunculus. 


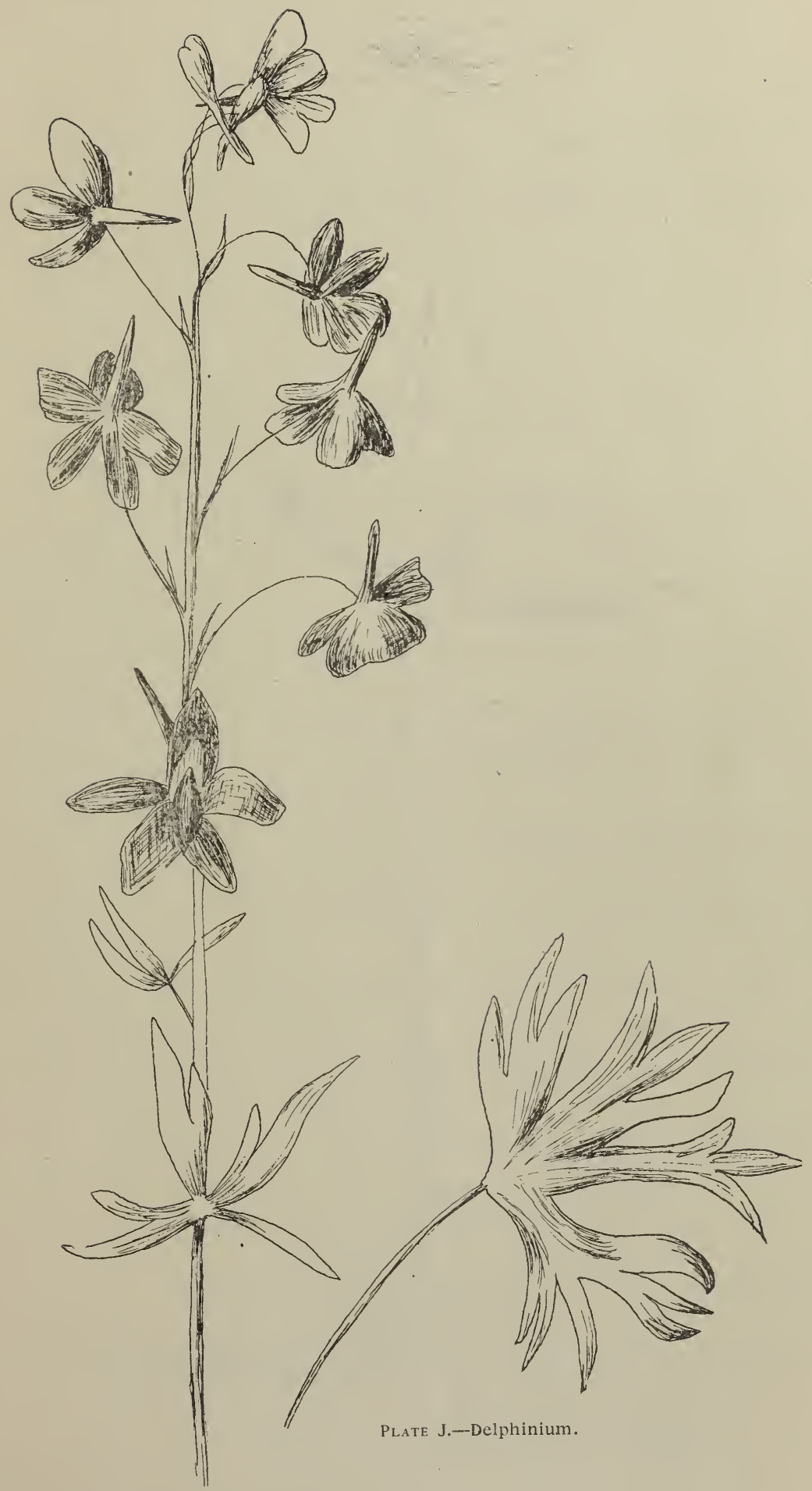




$$
\xi
$$


4) Ovary deeply four lobed. Borage Family (Boraginaceae).

5) Ovary cells as many as the petals. Heath Family (Ericaceae).

\section{Brief Description of a Few Plants}

\section{LILY FAMILY}

Parts of the floral envelope often much alike and the distinction of calyx and corolla sometimes difficult. Ovary three celled, stamens six facing inward.

I. Brodiaea. Wild Hyacinth (Plate E) flowers clustered at end of stock. There are a number of species.

2. True Lilies. Flowers on tall leafy stems. Mountain Lilies, Tiger Lilies, etc.

3. Fritillaria. Mission Bells, Rice Root. Simple leafy stem, bulb often with grains like rice, flowers nodding bell-shaped.

F. lanceolota. Checkered Lily, flower spotted with purple; common. (Plate A)

F. recurva. Scarlet spotted with yellow. Southern Oregon.

4. Erythronium. Dog-tooth Violet. Leaves broad of ten mottled, generally two at the base.

E. giganteum. The common cream-colored species. (Plate A).

E. hendersoni. Purple, bordered above with yellow. Southern Oregon.

5. Calochortus. Cats Ear. Species numerous.

6. Camassia esculenta, the common Camass. Blue sometimes white. (Plate A).

7. Trillium, Wake Robin. Three leaves in a whorl at top of stem. Leaves net veined.

Petals purple. T. petiolatum, Eastern Oregon.

Petals white, flower without stalk, leaves of ten spotted. R. chloropetalum.

Petals white chaging to rose and dark red, definite flower stalk. T. ovatum. (Plate A).

IRIS FAMILY

Floral envelope attached to ovary. Stamens three facing outward. 


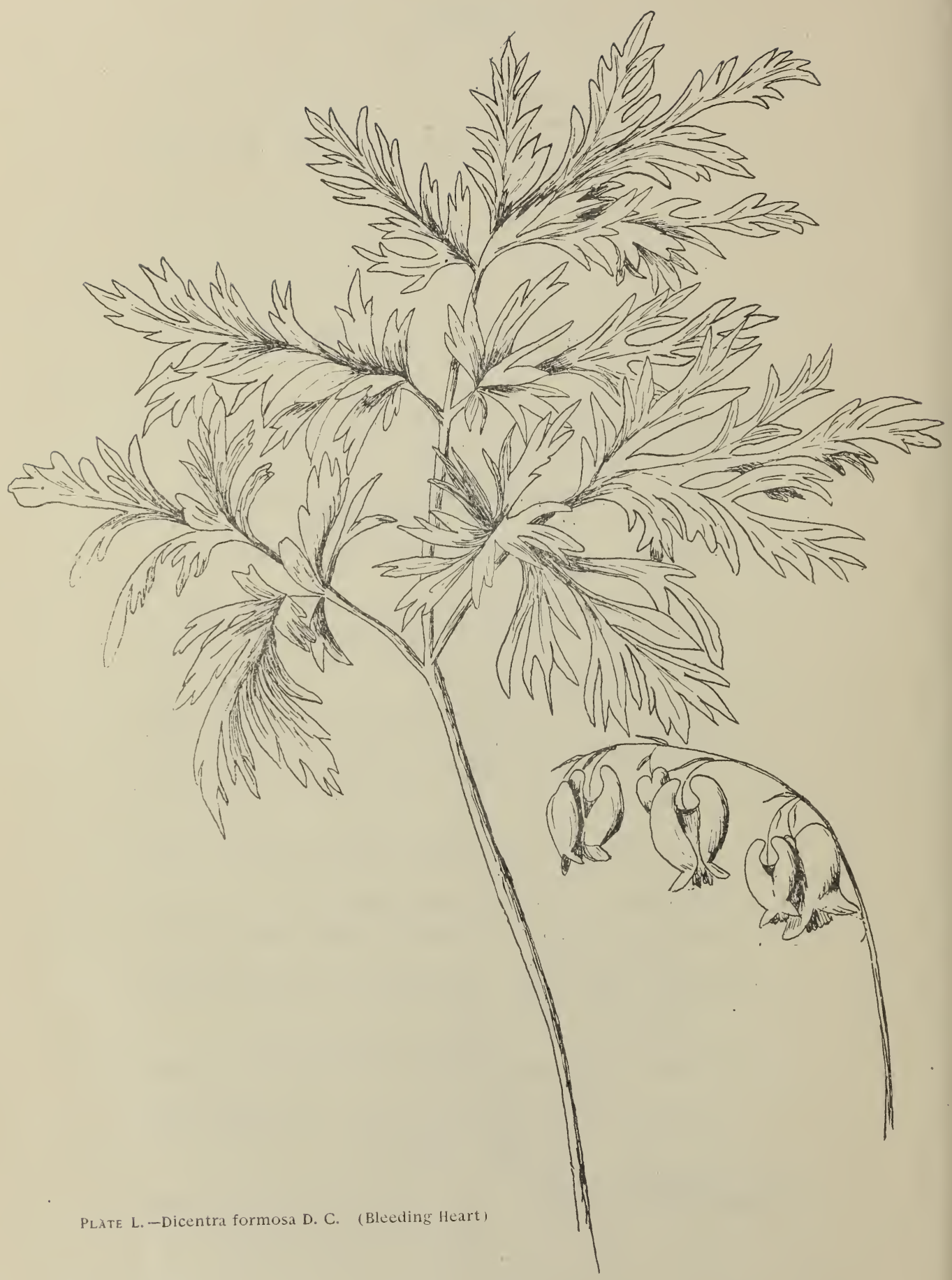




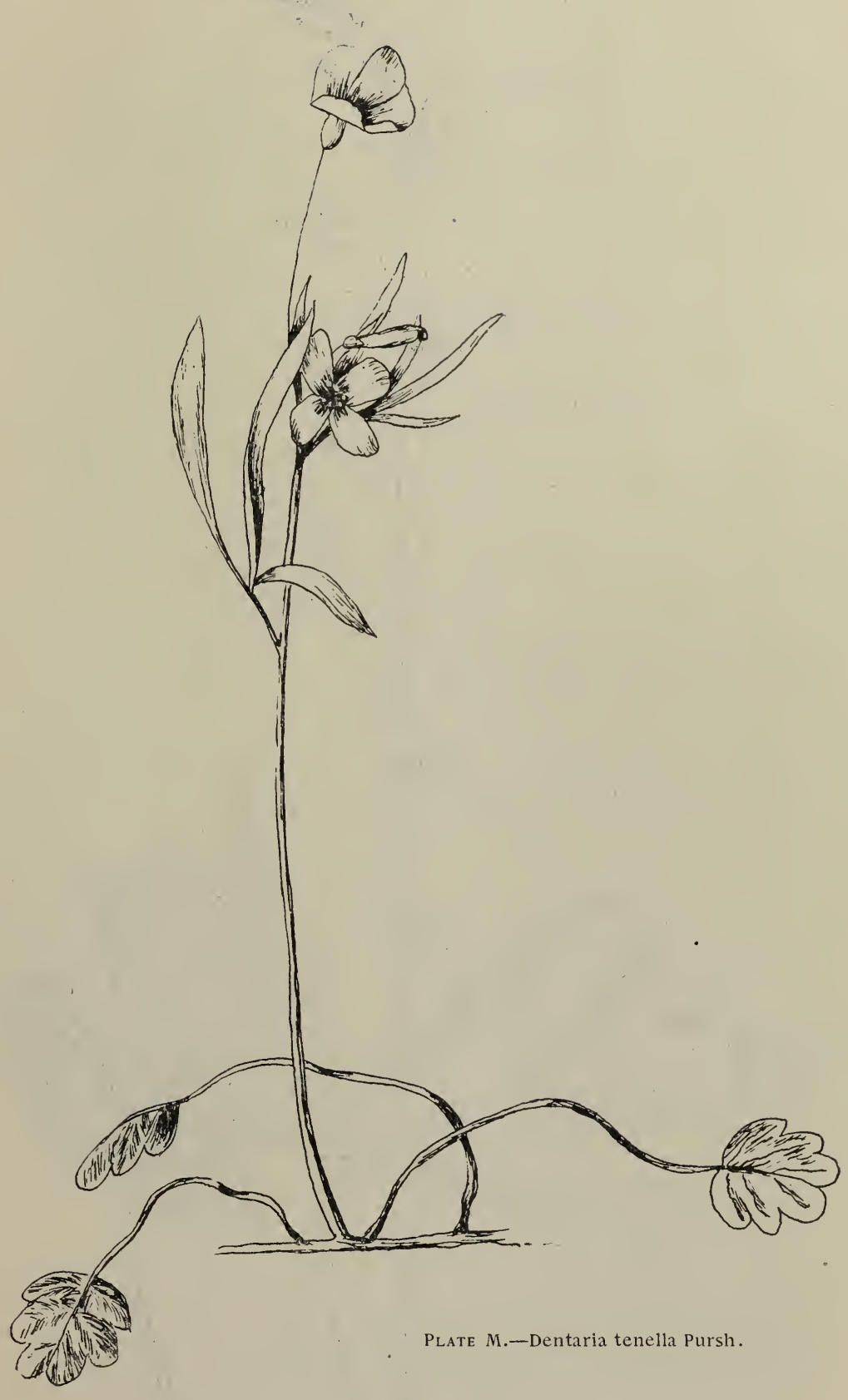




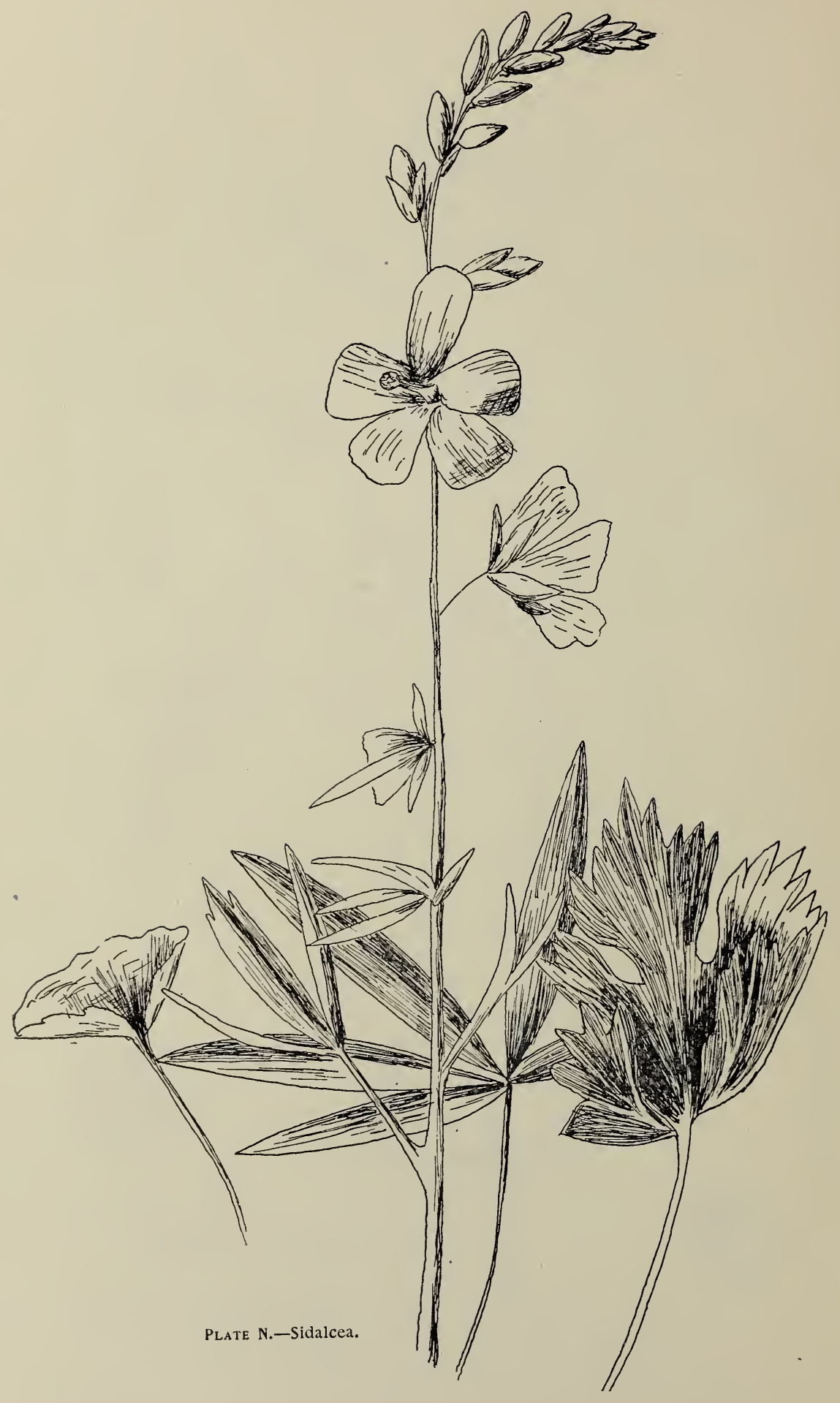


I. Iris. Blue Flag. The three sepals larger than the three petals.

2. Sisyrinchium. Blue-eyed Grass. (Plate F).

S. grandiflorum. The large flowered form.

S. bellum. The common form.

ORCHID FAMILY

This is a difficult family.

Here belong the Calypso, so well known and one of the early arrivals,

The Coral Root (Plate G)

The Ladies' Slipper and many other beautiful forms.

BUTTERCUP FAMILY

Parts of the flower all separate, petals sometimes wanting. Stamens and pistils numerous. Ovary simple.

I. Ranunculus. Buttercup, containing many species.

R. occidentalis (Plate $\mathrm{H}$ ). This is the common and early form of Western Oregon.

R. glaberrinus, the low early form of Eastern Oregon.

R. bolanderi. Common in wet places in Western Oregon, plant 111ore or less hairy, leaves compound, petals purple on the outside.

2, Delphinium. The Larkspur. Flower irregular, furnished with a definite spur (Plate J). A large genus and somewhat difficult of determination. The common low form is $\mathrm{D}$. menziesii.

3. Anemoe. Wind flower.

A. deltoidea (Plate $\mathrm{K}$ ).

In the buttercup family belong Clematis, Columbine, Aconite, etc. POPPY FAMILY

Here is found the California Poppy, Eschscholtzia californica.

BLEEDING-HEART FAMILY

Dicentra formosa. Is the common bleeding-heart of the woods (Plate L).

\section{VIOLET FAMILY}

I. Viola nuttallii. Is the low early form, the Johnny Jump-up.

2. V. glabella. The tall yellow form growing in moist places.

3. V. adunca. The low blue form.

PORTULACA

Here belong a great variety of fleshy plants of the genus Monita growing in moist places, coming early and flowering till late, sometimes called Miner's or Chinese Lettuce. 


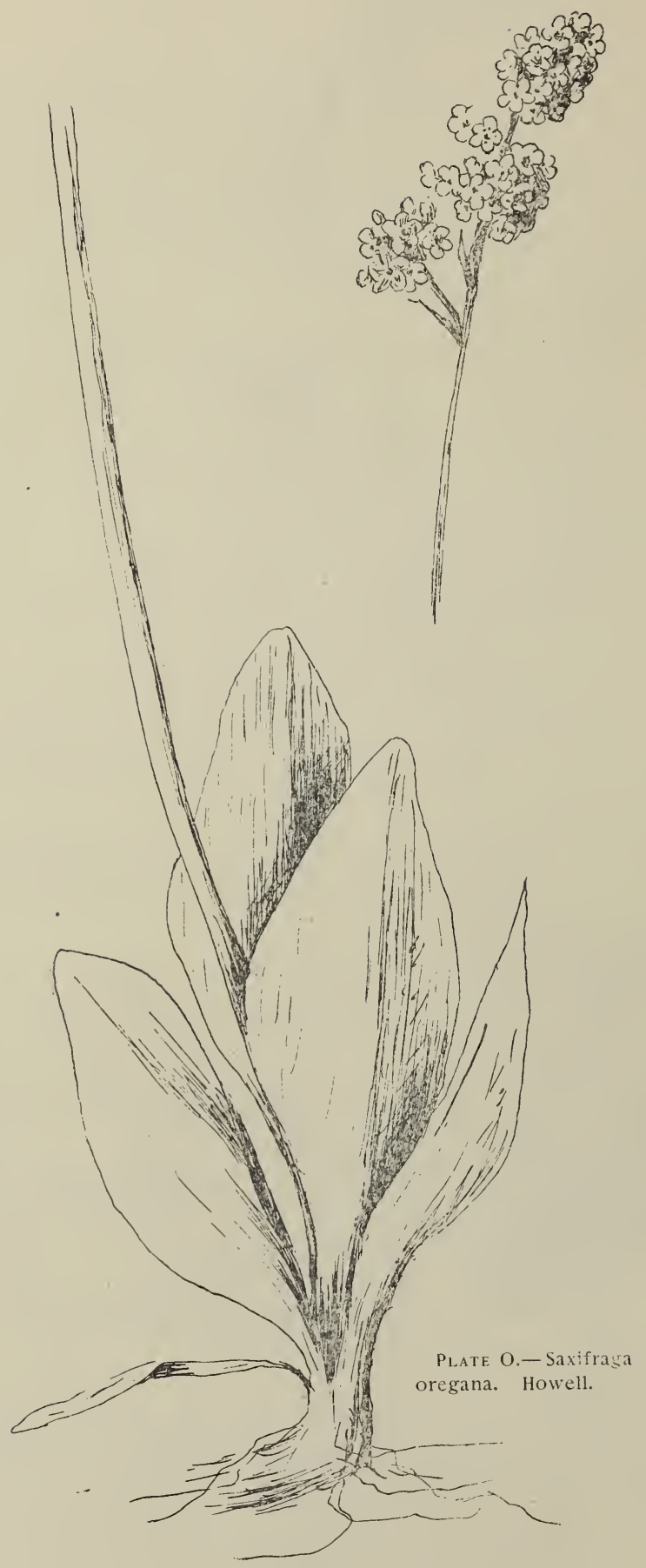




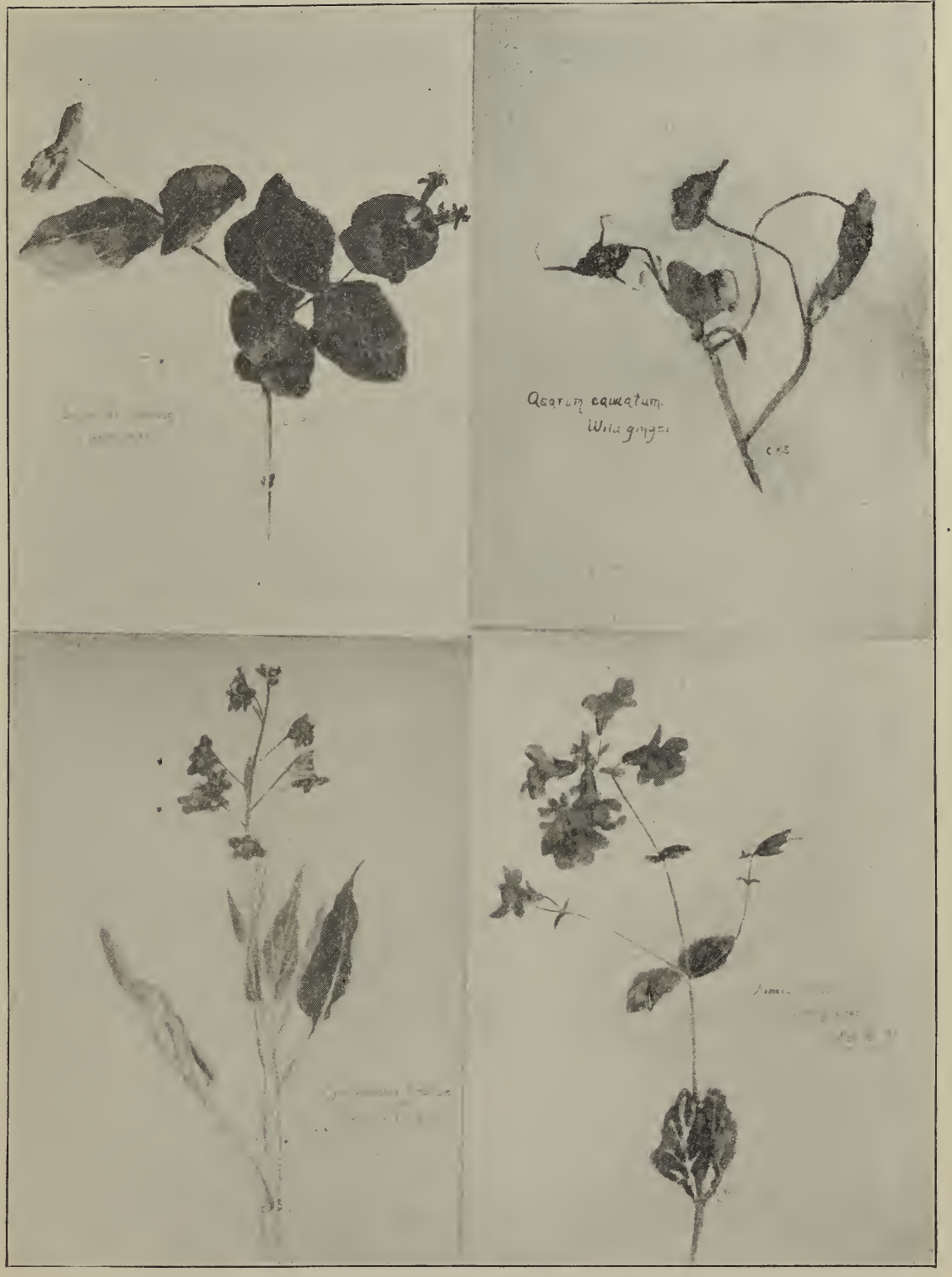

Pl.ate P. 


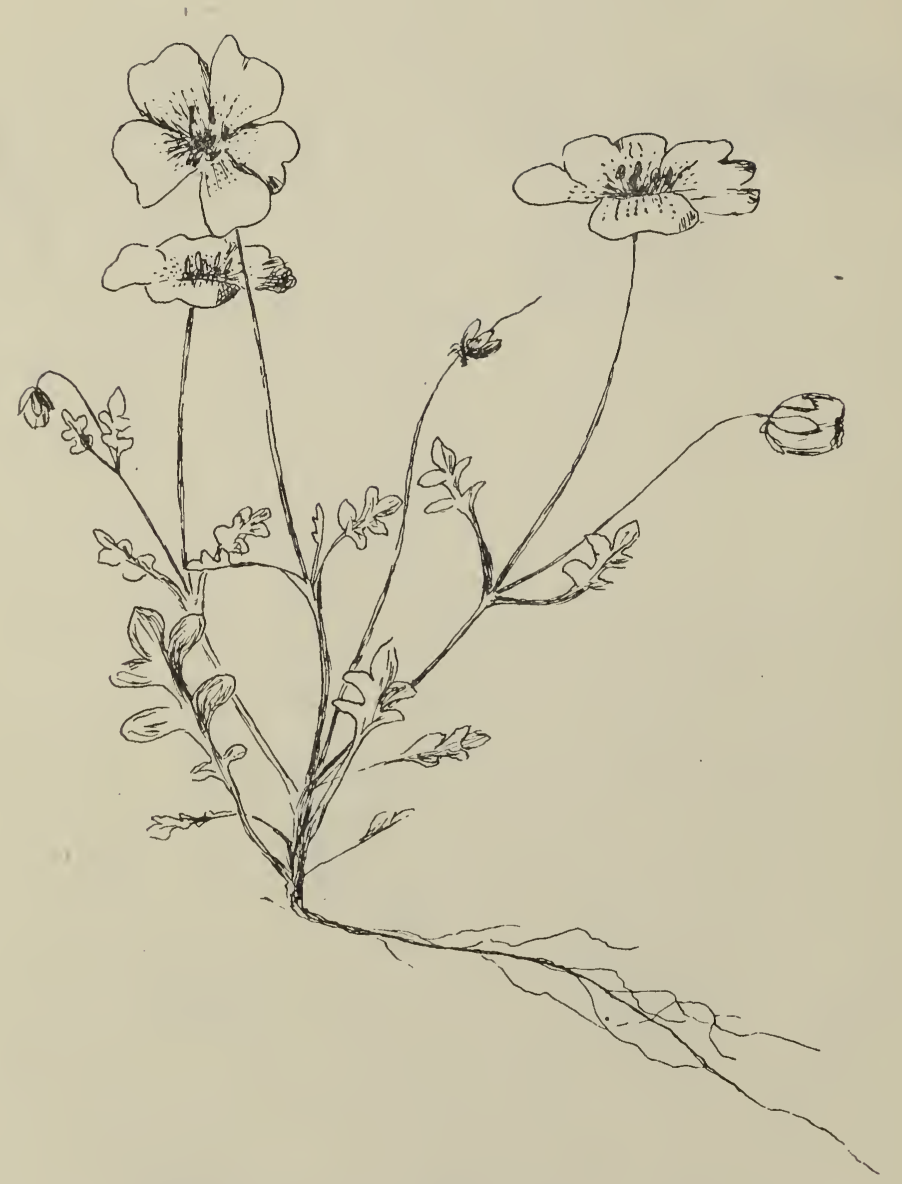

Plate Q.-Nemophila menziesii. H. \& A. 
MUSTARD FAMILY

Petals four forming a cross, hence the name of the family-Cruciferae. Stamens six, two shorter, four longer. Fruit a two celled pod. A large family including the Mustard, Cress, Radish, etc.

Dentaria tenella. Pepper-root (Plate M) belongs here. This is one of the earliest flowers. Sometimes called Spring Beauty. This is an excellent form with which to begin the study of the flower, since it can be so readily obtained. It may used instead of the flax flower, and the outline for the latter will, for the most part, apply equally well.

MALLOW FAMILY

More or less showy flowers, with five petals joined to the stamens which are united into a tube enclosing the pistils. The fruit makes the "clieeses" of the children.

Sidalcia (Plate N). Is a good type of the mallow. These are numerous but their distinction depends upon characteristics which cannot be considered here.

\section{SAXIFRAGE FAMILY}

Herbs or shrubs.

Saxifraga oregona (Plate O). Is a good example of the herbaceous forms; and

The Currant, Gooseberry and Syringa of the shrubs.

\section{HONEYSUCKLE FAMILY}

Lonicera cilliosa (Plate $\mathrm{P}$, upper right hand figure) climbing. Corolla scarlet without, yellow within. Upper leaves perfoliate.

L. involucrata. Shrub, leaves never united. Corolla yellow. Flowers in pairs surrounded by a leafy involucre. Fruit black, involucre becoming red.

FIGWORT FAMILY

Mimulus langsdorfii (Plate P, lower left hand). Yellow with brown or red spots in the throat. Grows in wet places. There are numerous other species.

BABY-EYES FAMILY

Nemophila menziesii (Plate $Q$ ). Very common in the early spring in the pastures.

\section{PRIMROSE FAMILY}

Dedecatheon hendersoni. The Birds-bill (Plate R). The illustration shows the process of cross-pollination.

\section{PHLOX FAMILY}

Gilia tenella (Plate S). But a simple illustration of this large family.

BORAGE FAMILY

Cynogossum grande (Plate P, lower right hand). A coarse weed flowering early.

The ovary of the borage much resembles the inint family but the corolla is generally regular. 


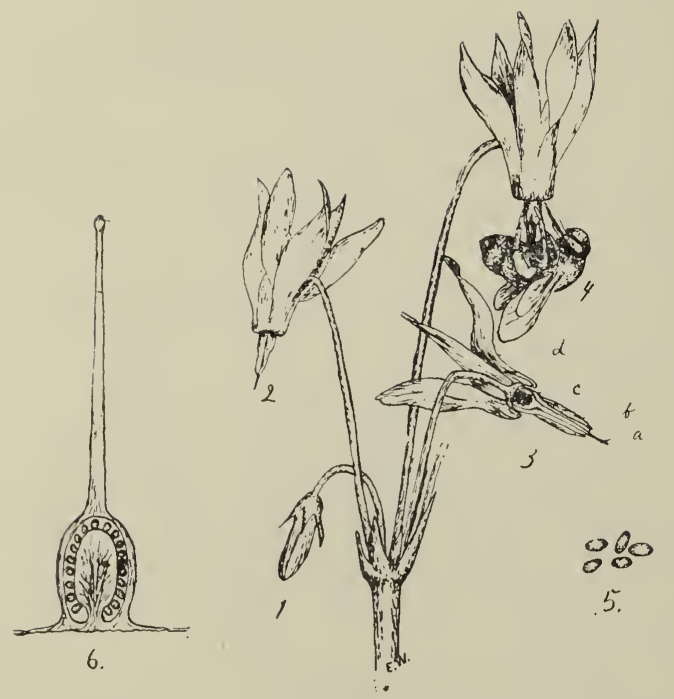

Crow-bill (Dodecatheon Hendersonii).

Plate R. 


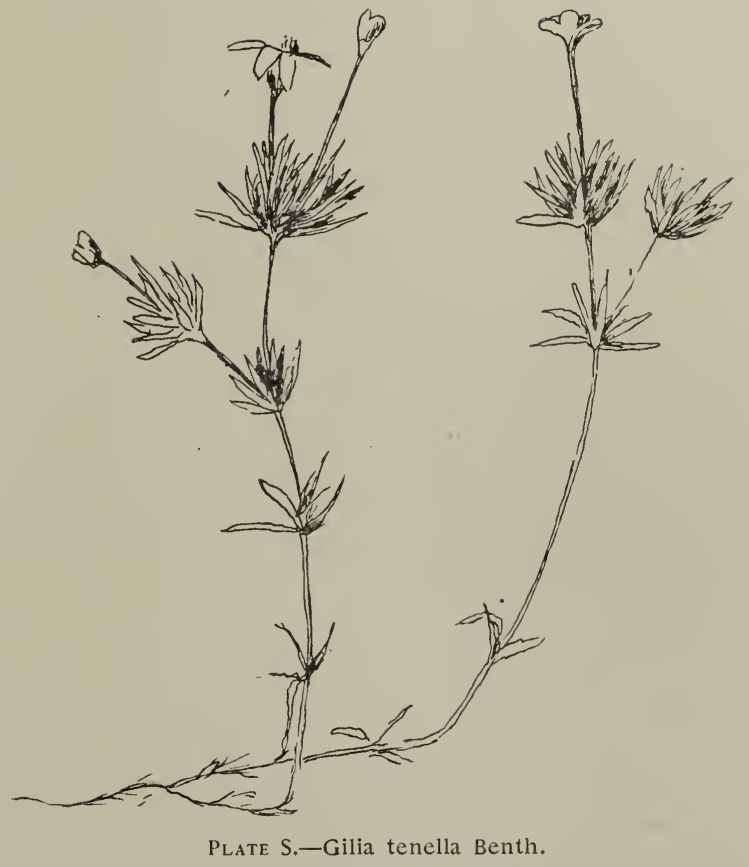





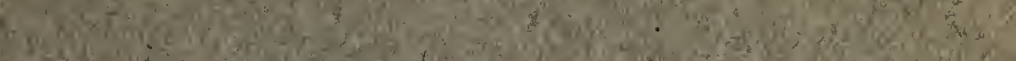

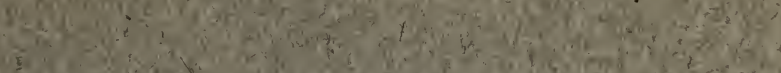

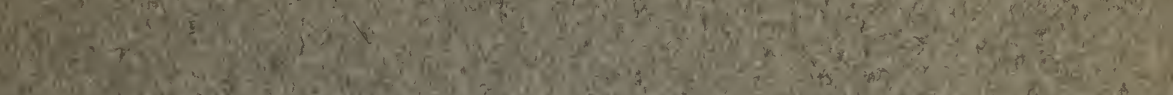
Ly

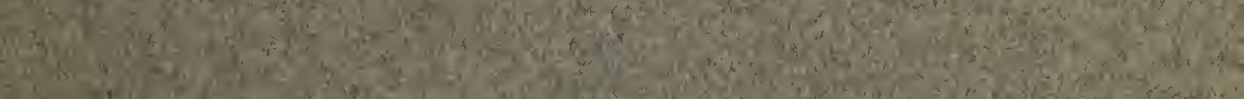

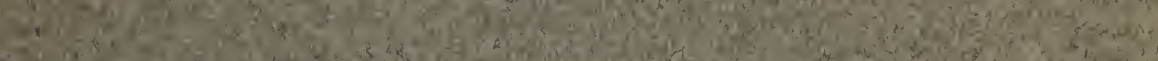
a

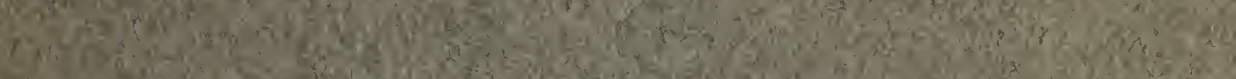
Now S

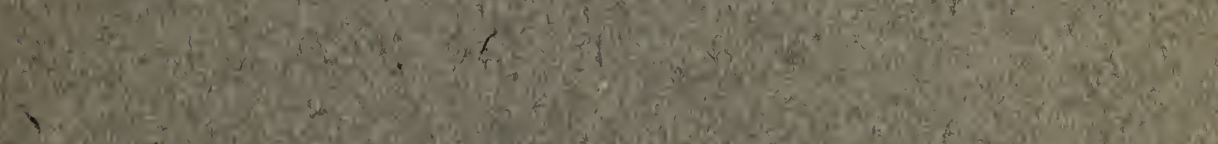

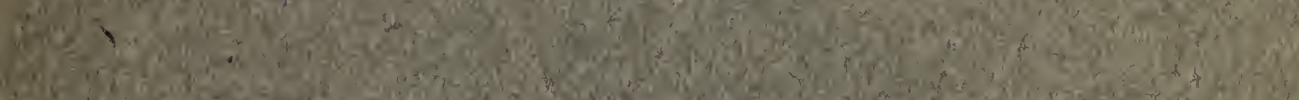

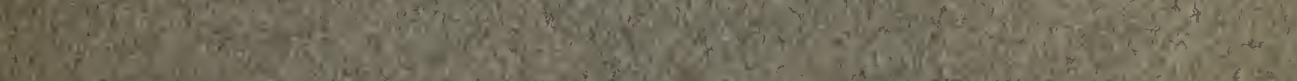

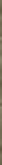

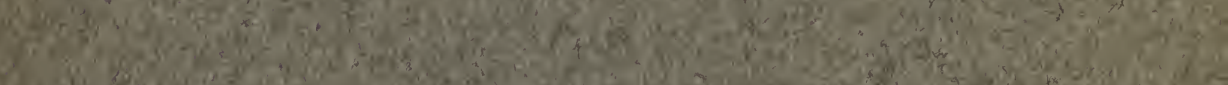
4.

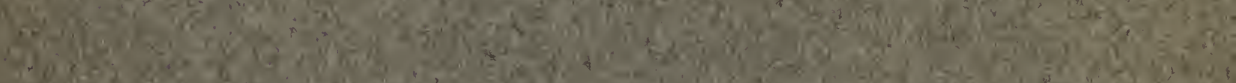

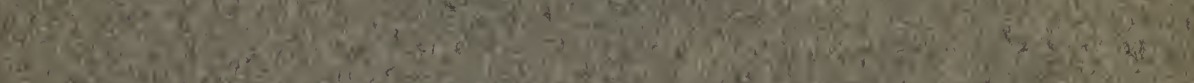

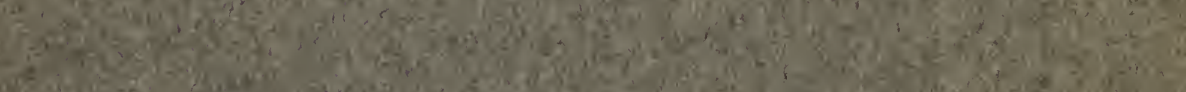

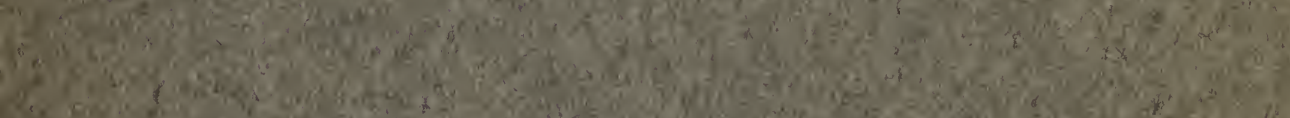

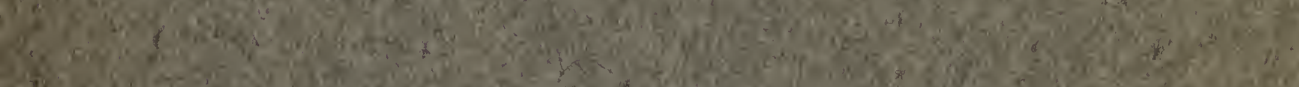

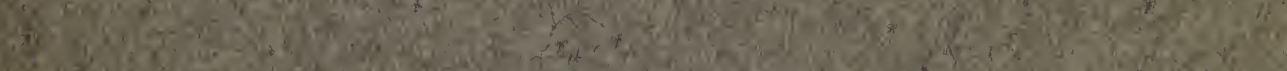

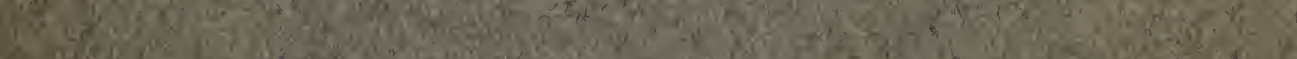

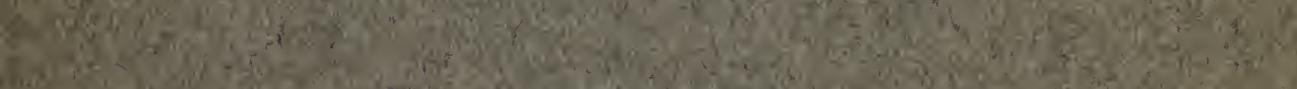
4 (3)

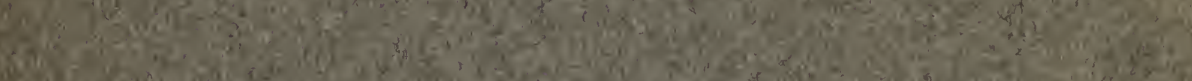

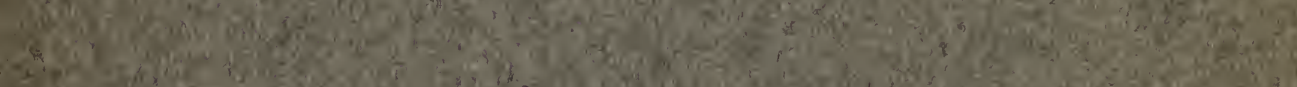

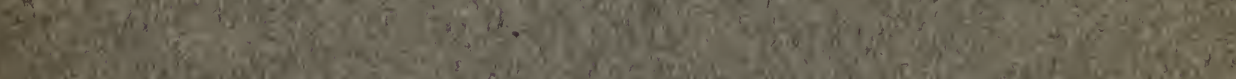

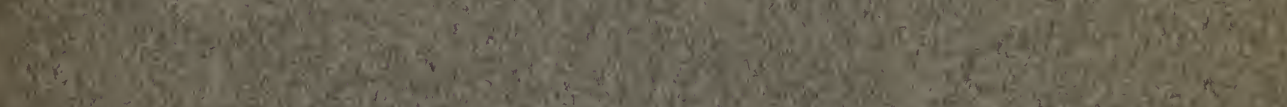

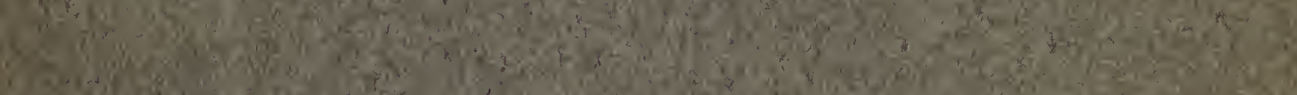

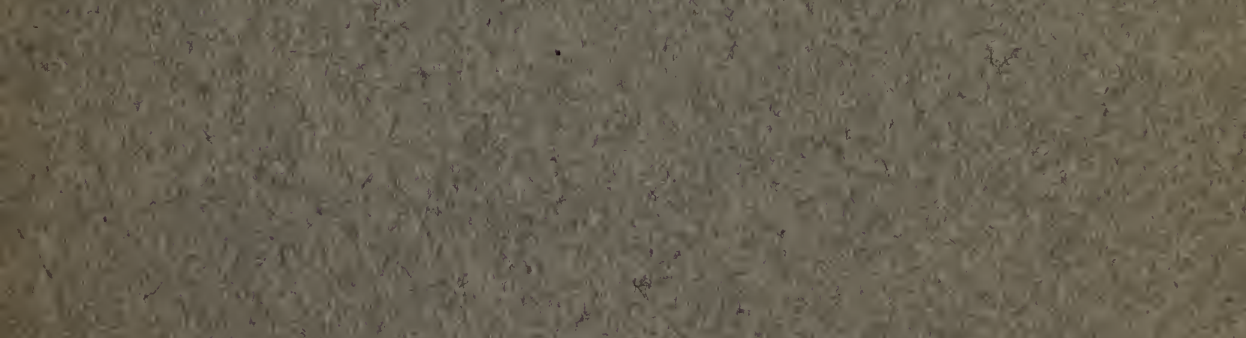


